\title{
Cause-Related Marketing Sebagai Kampanye Solidaritas dan Dampaknya Pada Perilaku Konsumen di Masa Pandemi Covid-19
}

\author{
Nurkholish Majid ${ }^{1, *}$, Nanik Hariyana ${ }^{2}$ \\ ${ }^{1,2}$ Universitas Pembangunan Nasional "Veteran" Jawa Timur, Surabaya, Indonesia \\ *Email: nurkholish.majid.ma@upnjatim.ac.id
}

\begin{abstract}
Covid 19 Desease has impact for society purchase power decrease for product and service ini several sectors especially fastfood restaurant services. Burger King as one of fastfood restaurant sector make a strategy to attract consumer intention to buy its competitors'and several local brand culinary product through social media campaign. Purpose of this research examine how effect of Burger King campaign which formed as Caused Related Marketing (CrM) to Brand image, Attitude and Purchase Intention. Research using structural analysis with GeSCA method. Research sample are 120 respondents who know Burger King campaign from social media. Result presents that CrM has impact on Brand image and Attitude. Then Brand image has impact on Attitude. Attitude has impact on Purchase Intention. But CrM and Brand image has no effect on Purchase Intention.
\end{abstract}

Abstraksi: Pandemi Covid 19 memberikan dampak pada penurunan daya beli masyarakat terhadap produk dan jasa di berbagai sektor tak terkecuali layanan jasa restoran cepat saji. Burger King sebagai salah satu pelaku usaha restoran cepat saji membuat sebuah strategi guna menarik minat pembelian konsumen melalui kampanye di sosial media untuk melakukan pembelian di restoran cepat saji pesaing dan beberapa pelaku usaha kuliner merek lokal. Penelitian ini mengkaji bagaimana pengaruh kampanye Burger King dalam bentuk Caused Related Marketing (CrM) terhadap Brand image, Sikap dan Minat. Penelitian menggunakan analisis persamaan strukural dengan metode GeSCA. Sampel penelitian adalah 120 Responden yang mengetahui kampanye Burger King melalui sosial media. Hasil penelitian menunjukkan bahwa CrM memberikan dampak pada Brand image dan Sikap. Selain itu Brand image memberikan dampak pada Sikap. Sikap memberikan pengaruh pada Minat Pembelian. Namun CrM dan Brand image tidak berpengaruh terhadap Minat Pembelian.

Keywords: Caused Related Marketing; Brand image; Attitude and Purchase Intention

\section{Pendahuluan}

Pandemi Covid-19 mempengaruhi berbagai aspek kehidupan khususnya di bidang ekonomi. Wabah yang telah berlangsung hampir satu tahun ini memberikan dampak pada turunnya angka pertumbuhan ekonomi hingga membawa perekonomian suatu negara masuk ke dalam jurang resesi. Di Indonesia angka pertumbuhan ekonomi mengalami penurunan hingga sebesar $-3,2 \%$ di kuartal 4 Indonesia. Penurunan tersebut terjadi dua kali berturutturt sehingga mengindikasikan bahwa Indonesia sudah masuk ke dalam tahap resesi ekonomi (Badan Pusat Statistik, 2020). Salah satu faktor penyebab turunnya nilai pertumbuhan ekonomi tersebut diantaranya adalah rendahnya daya beli masyarakat sehingga perputaran roda perekonomian tidak berjalan dengan baik. Penurunan daya beli dapat dilihat angka inflasi yang terus menurun hingga $-0,5 \%$ di bulan september 2020, khusus di industri makanan dan minuman angka inflasi mencapai $-0,9 \%$ yang menjadikan sektor ini adalah yang paling terkena dampak dari rendahnya daya beli masyarakat di masa pandemi Covid-19 (Badan Pusat Statistik, 2020). Berbagai usaha telah dilakukan oleh pemerintah guna meningkatkan daya beli masyarakat melalui berbagai program stimulus bantuan yang telah diberikan secara bertahap serta menjangkau berbagai elemen masyarakat. Namun demikian pertumbuhan ekonomi akan membaik jika aktivitas telah berjalan normal kembali bila pandemi Covid-19 benar-benar berakhir.

Rendahnya daya beli masyarakat dalam industri makanan dan minuman lantas membuat para pelaku usaha merumuskan beberapa strategi guna meningkatkan penjualan dan menarik minat pembelian konsumen. Salah satu kegiatan yang dilakukan yakni dengan kampanye melalui sosial media yang dilakukan oleh pelaku usaha restoran cepat saji. Burger King 
melakukan kampanye melalui sosial media dengan cara mempromosikan beberapa merek pesaingnya sebagai bentuk solidaritas karena penjualan mereka menurun di saat pandemi. Pesan yang disampaikan melalui sosial media tersebut berisi permintaan kepada konsumen untuk melakukan pembelian di restoran pesaingnya seperti Mc Donald, KFC dan beberapa merek lokal lainnya agar dapat tetap bertahan selama pandemi terus berlangsung seperti dinujukkan pada Gambar 1.

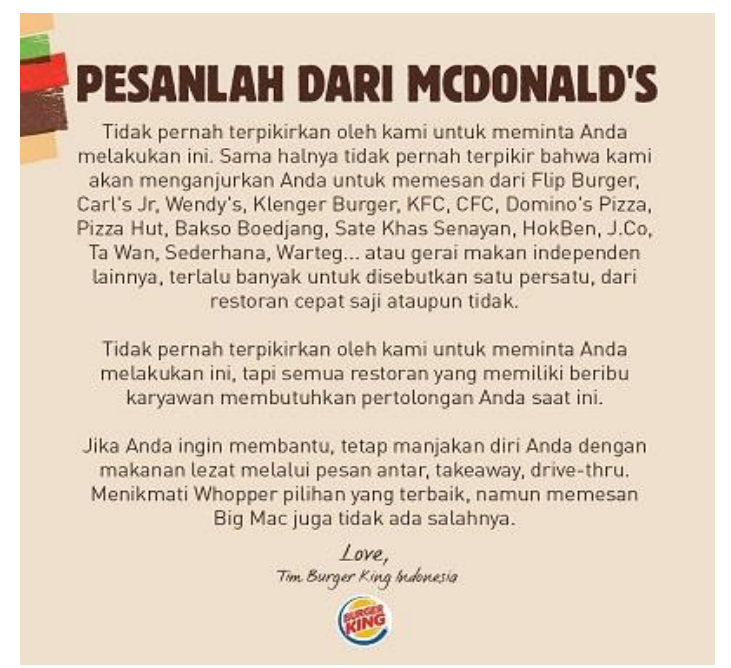

Gambar 1. Kampanye Burger King

Sumber: Instagram Burger King (2020)

Kampanye tersebut juga mendapat respon dari beberapa pelaku usaha lain melalui media sosial yakni mempromosikan produk yang ditawarkan Burger King dan restoran cepat saji lainnya sebagai bentuk solidaritas sesama pelaku usaha makanan cepat saji baik dari mancanegara maupun lokal. Kampanye tersebut pada akhirnya menjadi viral di sosial media dan mendapatkan tanggapan positif dari pengguna internet yang ingin memberikan solidaritas mereka kepada merek-merek makanan cepat saji lokal maupun mancanegara agar dapat menghadapi penurunan penjualan di masa pandemi. Kampanye solidaritas yang dilakukan oleh Burger King tersebut bila ditinjau dari segi teori pemasaran disebut dengan Caused-related Marketing (CrM).

CrM merupakan sebuah kegiatan pemasaran yang bertujuan non-ekonomis guna meningkatkan kesejahteraan sosial melalui sumber daya perusahaan maupun mitra perusahaan tersebut (Kotler \& Keller,
2015). CrM yang merupakan salah satu bentuk tanggung jawab sosial ini mampu mendorong konsumen untuk berempati lalu membangun sikap yang positif terhadap sebuah usaha yang melakukan kegiatan tersebut (Eastman et al., 2019). CrM mampu memberikan citra positif terhadap perusahaan sehingga mampu mendorong minat konsumen melakukan pembelian produk yang ditawarkan (Lin \& Lin, 2019). Konsumen akan melakukan evaluasi terhadap melalui aktivitas yang dilakukan perusahaan seperti kampanye, sehingga memunculkan tanggapan positif yang ditunjukkan dari sikap dan minat terhadap produk yang akan dibeli (Diehl et al., 2016). CrM tidak hanya sekedar aktivitas yang menaikkan profit namun juga upaya solidaritas dan membantu sesama menjadi sebuah strategi pemasaran yang efektif sehingga mampu meningkatkan ketertarikan konsumen terhadap pembelian produk (Maharani Feminingtyas \& Mayangsari, 2020). CrM menjadi sebuah sarana komunikasi yang efektif ketika berada di momentum yang krusial sehingga mampu mendorong mereka dalam melakukan pembelian produk yang ditawarkan. Kesesuaian tindakan dalam $\mathrm{CrM}$ merepresentasikan kebijakan untuk membantu sesama yang pada akhirnya mampu membangun ketertarikan konsumen terhadap perusahaan (Baek et al., 2017). Keterlibatan konsumen dalam kampanye kepedulian melalui CrM mampu membangun sikap positif dalam mendorong dalam pembelian suatu produk (Patel et al., 2017).

Fenomena solidaritas pelaku usaha makanan cepat saji dalam bentuk kampanye melalui sosial media ini menjadi kajian yang menarik guna menjelaskan bagaimana peran kampanye solidaritas sebagai sebuah sarana untuk membangun Brand image, sikap dan minat konsumen dalam melakukan pembelian di masa pandemi Covid 19. Fenomena yang dikategorikan sebagai bentuk CrM ini secara teoritis mampu memberikan tanggapan positif dari konsumen yang ditunjukkan dalam bentuk sikap mereka terhadap merek pelaku usaha cepat saji hingga menarik minat untuk melakukan pembelian terhadap produk. Dengan demikian penelitian ini bertujuan untuk menjelaskan: (1) Bagaimana pengaruh CrM terhadap Brand image; (2) Bagaimana 
pengaruh CrM terhadap Sikap; (3) Bagaimana pengaruh CrM terhadap Minat Pembelian; (4) Bagaimana pengaruh Brand image terhadap Sikap; (5) Bagaimana pengaruh Brand image terhadap Minat Pembelian; dan (6) Bagaimana pengaruh Sikap terhadap Minat Beli.

\section{Kajian Teori}

CrM membentuk persepsi konsumen dengan membangun sebuah kesadaran sebuah merek yang dibangun dalam bentuk kepedulian sosial dari perusahaan terkait dengan masalah yang sedang terjadi saat ini atau dikenal dengan social concern (Lerro et al., 2019). Ketika sebuah perusahaan dengan merek tertentu melaksanakan kegiatan kampanye CrM maka akan membangun kesesuaian pelanggan terhadap merek sehingga memunculkan persepsi positif terhadap merek tersebut (Baek et al., 2017). Patel et al (2017) menjelaskan bahwa kegiatan CrM mampu menghasilkan pandangan dan kesan positif terhadap sebuah merek sehingga menjadi bentuk sikap yang diwujudkan dalam bentuk keinginan untuk melakukan produk yang ditawarkan merek tersebut. Kegiatan CrM yang dilakukan secara masif melalui media sosial memberikan efektivitas terhadap kesadaran konsumen terhadap sebuah merek namun tidak serta merta mampu memberikan stimulus kepada konsumen untuk melakukan pembelian produk. (Cho et al., 2017) menambahkan bahwa kegiatan CrM yang dipersepsikan sebagai sebuah kebaikan oleh konsumen mampu menghasilkan dorongan terhadap pembelian suatu produk merek tertentu demikian pula dengan pandangan positif terhadap merek itu sendiri.

\section{Hubungan antara CrM dengan Brand image}

Konsumen akan memberikan apresiasi dan menilai perusahaan tidak hanya mengejar keuntungan semata bila perusahaan menerapkan kegiatan CrM sebagai bentuk kepedulian sosialnya sehingga mampu membangun reputasi yang baik ditunjukkan dengan peningkatan image perusahaan di mata konsumen (Hashem, 2020). Lin \& Lin (2019) menjelaskan bahwa kegiatan CrM dalam bentuk penggalangan dana mampu memberikan pandangan positif akan kepedulian sosial perusahaan terhadap lingkungan sekitar sehingga mampu membangun citra yang positif perusahaan dari sudut pandang konsumen. Kampanye positif yang dibangun perusahaan melalui CrM akan meningkatkan kesadaran merek perusahaan oleh konsumen sehingga mampu membentuk citra yang positif konsumen terhadap sebuah merek (Surianto et al., 2020). Dengan demikian maka hipotesis yang dirumuskan adalah $\mathrm{H} 1$ : CrM memiliki pengaruh terhadap Brand image.

\section{Hubungan antara CrM dengan Sikap}

Kredibilitas yang terbangun dalam $\mathrm{CrM}$ mampu menghasilkan sikap yang positif terhadap sebuah merek yang menjadi sebuah alat yang efektif guna meningkatkan reputasi perusahaan (Eastman et al., 2019). Pandey (2020) menjelaskan bahwa CrM menjadi sebuah alat pemasaran yang efektif dalam menghasilkan sikap positif terhadap sebuah produk ditinjau dari segi lamanya kampanye serta jenis perusahaan yang melaksanakan kegiatan CrM tersebut. Duarte \& Silva (2018) menjelaskan bahwa CrM yang efektif diukur dari kemampuan konsumen dalam mengidentifikasi manfaat kampanye kebaikan dari sebuah perusahaan sehingga akan memberikan peningkatan sikap yang positif dan respon terhadap perusahaan lebih baik. Dengan demikian maka hipotesis yang dirumuskan adalah $\mathrm{H} 2$ : $\mathrm{CrM}$ memiliki pengaruh terhadap Sikap.

\section{Hubungan antara CrM dengan Minat Beli}

Promosi dalam bentuk CrM menjadi sebuah bentuk strategi pemasaran yang efektif untuk produk hedonis karena sensitifitas produk yang tertutupi oleh iklan kebaikan dari CrM yang dilakukan perusahaan mampu menghasilkan pembelian lebih besar dibandingkan perusahaan yang tak melakukan CrM (Partouche et al., 2020). Chaabouni et al. (2020) menjelaskan bahwa kegiatan CrM berperan dalam membentuk ketertarikan konsumen terhadap pembelian produk yakni ketika semakin tinggi donasi yang dihasilkan serta minimnya stigma negatif terhadap keraguan atau skeptisme konsumen terhadap kegiatan CrM. CrM menjadi sebuah alat pemasaran yang efektif ketika konsumen mampu memahami tujuan positif dari kampanye tersebut sehingga mampu mendorong konsumen dalam melakukan pembelian (Ferraris et al., 2019). Dengan demikian hipotesis yang dirumuskan adalah 
H3: CrM memiliki pengaruh terhadap Minat Pembelian.

\section{Hubungan antara Brand image dengan Sikap}

Cho et al (2017) menjelaskan bahwa Brand image tidaklah mampu menghasilkan perannya sendiri tanpa sikap terhadap brand dalam mendorong konsumen melakukan pembelian. Sikap terhadap produk mampu dibangun oleh Brand image yang baik sehingga muncul persepsi yang positif terhadap sebuah produk/merek (Wulandari \& Riptiono, 2020). Brand image mampu membangun persepsi konsumen terhadap suatu merek baik secara positif maupun negatif yang didasarkan pada pengalaman reflektif ketika melakukan evaluasi terhadap sebuah merek (Ramesh et al., 2019). Dengan demikian maka hipotesis yang dirumuskan adalah H4: Brand image memiliki pengaruh terhadap Sikap

\section{Hubungan Brand image dengan Minat Beli}

Brand image yang baik mampu menghasilkan sikap positif terhadap merek tersebut sehingga mampu mendorong konsumen dalam melakukan pembelian produk (Park \& Sihombing, 2020). Duarte \& Silva (2018) menambahkan bahwa cara yang paling tepat dalam menarik minat konsumen adalah dengan melakukan kegiatan periklanan yang mampu menunjang citra sebuah merek sehingga mampu meningkatkan pandangan emosional yang positif dalam membangun hubungan terhadap konsumen dan merek. Brand image memiliki peran yang dominan dalam membangun minat pembelian konsumen karena adanya keyakinan mutu yang telah dibangun oleh sebuah merek dan terasosiasi dalam pikiran konsumen (Wijayayanto, 2018). Dengan demikian dirumuskan hipotesis H5: Brand image memiliki pengaruh terhadap Minat Pembelian.

\section{Hubungan antara Sikap dengan Minat Beli}

Charton-Vachet et al. (2020) menjelaskan bahwa sikap konsumen terhadap sebuah merek memiliki sebuah stigma tersendiri sehingga menjadi sebuah pertimbangan atau preferensi tersendiri dalam pemilihan sebuah produk yang akan dibeli oleh konsumen. Dalam mengkaji sebuah produk yang akan diminati oleh konsumen atau tidak harus mempertimbangkan bagaimana pandangan konsumen terhadap produk tersebut melalui sikap positif yang dihasilkan (Kasilingam, 2020). Sikap positif konsumen dalam menanggapi sebuah merek yang dibangun dalam serangkaian periklanan akan menghasilkan dorongan kepada konsumen dalam melakukan pembelian (Partouche et al., 2020). Dengan demikian dirumuskan hipotesis yakni H6: Sikap memiliki pengaruh terhadap Minat Pembelian

\section{Metode}

Penelitian menggunakan pendekatan kuantitatif. Metode pengumpulan data dilakukan dengan menggunakan instrumen penelitian yakni kuesioner yang sumber datanya diperoleh langsung dari responden penelitian. Dalam kondisi pandemi maka kuesioner akan disebarkan secara online melalui google form.

Populasi penelitian adalah Pengguna sosial media yang telah mengetahui Kampanye Solidaritas Burger King. Selain itu kriteria populasi adalah Konsumen pada rentang usia 12 hingga 29 tahun. Hal tersebut sesuai dengan segmen restoran makanan cepat saji yang didominasi oleh pemuda dari usia 12 hingga 29 tahun (Wiguno et al., 2014). Pengambilan sampel dilakukan dengan metode non-probability sampling dan teknik purposive sampling atau sampel dengan kriteria. Kriteria sampel antara lain: (1) konsumen potensial restoran makanan cepat saji; (2) konsumen yang memahami kampanye solidaritas dari pelaku usaha makanan cepat saji di sosial media; (3) konsumen yang berada di segmen yang sesuai dengan restoran makanan cepat saji yakni antara 12 hingga 29 tahun. Jumlah sampel penelitian berdasarkan perhitungan dari jumlah indikator/item yang berjumlah 12 dikali dengan 10 sehingga berjumlah 120 (Hair et al., 2009).

Pengolahan data dilakukan dengan analisis persamaan struktural melalui metode Generalized Structured Component Analysis (GeSCA) yang menguji hubungan antar variabel melalui analisis inner model dan hubungan antara variabel dan item melalui analisis outer model. Selain itu digunakan analisis statistik deskriptif guna menjelaskan 
Tabel 1. Item Pertanyaan

\begin{tabular}{|c|c|c|c|}
\hline No. & Variabel & Item Pertanyaan & Sumber \\
\hline \multirow[t]{3}{*}{1.} & \multirow[t]{3}{*}{$\mathrm{CrM}$} & $\begin{array}{l}\text { Menurut saya kampanye solidaritas yang dilakukan Burger } \\
\text { King sangat bermanfaat }\end{array}$ & \multirow[t]{3}{*}{ Lerro et al. (2019) } \\
\hline & & $\begin{array}{l}\text { Menurut saya kampanye solidaritas yang dilakukan Burger } \\
\text { King cukup bagus }\end{array}$ & \\
\hline & & $\begin{array}{l}\text { Menurut saya kampanye solidaritas yang dilakukan Burger } \\
\text { King mengagumkan. }\end{array}$ & \\
\hline \multirow[t]{3}{*}{3.} & \multirow{3}{*}{$\begin{array}{l}\text { Brand } \\
\text { image }\end{array}$} & Menurut Saya Burger King adalah merek yang terkenal & \multirow[t]{3}{*}{ Cho et al. (2017) } \\
\hline & & Menurut saya Burger King adalah merek yang unik & \\
\hline & & Menurut saya Burger King adalah merek yang familiar & \\
\hline \multirow[t]{3}{*}{3.} & \multirow[t]{3}{*}{ Sikap } & $\begin{array}{l}\text { Menurut saya Burger King adalah Restoran Cepat Saji yang } \\
\text { Bagus }\end{array}$ & \multirow[t]{3}{*}{ Patel et al. (2017) } \\
\hline & & $\begin{array}{l}\text { Menurut saya Burger King adalah Restoran Cepat Saji yang } \\
\text { Meyakinkan }\end{array}$ & \\
\hline & & $\begin{array}{l}\text { Menurut saya Burger King adalah Restoran Cepat Saji yang } \\
\text { Menarik }\end{array}$ & \\
\hline \multirow[t]{3}{*}{4.} & \multirow{3}{*}{$\begin{array}{l}\text { Minat } \\
\text { Pembelian }\end{array}$} & Saya memiliki keinginan untuk membeli Produk Burger King & \multirow[t]{3}{*}{ Baek et al. (2017) } \\
\hline & & $\begin{array}{l}\text { Saya memiliki pertimbangan untuk membeli Produk Burger } \\
\text { King }\end{array}$ & \\
\hline & & $\begin{array}{l}\text { Saya memiliki keinginan untuk merekomendasikan Produk } \\
\text { Burger King }\end{array}$ & \\
\hline
\end{tabular}

Sumber: Penelitian Terdahulu, diolah (2020)

demografi responden penelitian. Adapun item pertanyaan dijelaskan pada Tabel 1 .

\section{Hasil}

Penelitian menggunakan pendekatan kuantitatif dengan jenis penelitian eksplanatori yakni menjelaskan hubungan antar variabel yang diperoleh dari landasan hipotesis. Hasil analisis deskriptif terhadap 150 responden menunjukkan bahwa mayoritas responden adalah wanita sebesar $85,7 \%$ dan sisanya $14,3 \%$ adalah laki-laki. Berdasarkan usia mayoritas responden berusia 21-25 yakni 70,7\% sedangkan paling rendah adalah 26-29 yakni 7,3\%. Mayoritas responden mengetahui kampanye Burger King melalui Instagram yakni sebanyak $85,4 \%$ sedangkan yang paling sedikit menggunakan sosial media lain seperti Whatsapp dan lain-lain sebesar 26,8\%.

Dalam mengetahui uji kecocokan dan kelayakan model penelitian maka dilakukan analisis Goodness of Fit GFI dan FIT yang ditunjukkan pada Tabel 2.

\section{Tabel 2. Analisis Kecocokan Model}

\begin{tabular}{lclll}
\hline Kriteria & Angka & Keterangan & \\
\hline FIT & 0.752 & Memenuhi & \\
\hline GFI & 0.996 & $\begin{array}{l}\text { Memenuhi lebih besar } \\
\text { dari 0,9 }\end{array}$ & \\
\hline SRMR & 0.081 & Memenuhi & \\
\hline
\end{tabular}

Sumber: Data diolah (2020)

Berdasarkan hasil analisis kecocokan model diketahui nilai FIT sebesar 0,752 yang menunjukkan bahwa kontribusi variabel CrM, Brand image dan Sikap terhadap Minat Beli sebesar $75,2 \%$ sedangkan sisanya dijelaskan oleh variabel lain diluar penelitian. Hasil nilai GFI menunjukkan angka 0,996 yang nilainya di atas 0,9 sehingga menunjukkan model telah sesuai dan layak untuk dilakukan uji hipotesis (Hair et al., 2009).

Hasil Uji Validitas dan Reliabilitas ditunjukkan pada Tabel 3. 
Tabel 3. Uji Validitas dan Reliabilitas

\begin{tabular}{|c|c|c|c|c|}
\hline Variabel & Item & Loading Factor & Cronbach's Alpha & Keterangan \\
\hline \multirow{3}{*}{$\mathrm{CrM}$} & CrM 1 & 0.892 & \multirow{3}{*}{0,840} & \multirow{3}{*}{ Valid dan Reliabel } \\
\hline & CrM 2 & 0.941 & & \\
\hline & CrM 3 & 0.916 & & \\
\hline \multirow{3}{*}{ Brand image } & BI 1 & 0.889 & \multirow{3}{*}{0,830} & \multirow{3}{*}{ Valid dan Reliabel } \\
\hline & BI 2 & 0.803 & & \\
\hline & BI 3 & 0.901 & & \\
\hline \multirow{3}{*}{ Sikap } & Att1 & 0.934 & \multirow{3}{*}{0,947} & \multirow{3}{*}{ Valid dan Reliabel } \\
\hline & Att2 & 0.95 & & \\
\hline & Att3 & 0.965 & & \\
\hline \multirow{3}{*}{ Minat Beli } & PI1 & 0.949 & \multirow{3}{*}{0,874} & \multirow{3}{*}{ Valid dan Reliabel } \\
\hline & PI2 & 0.895 & & \\
\hline & PI3 & 0.828 & & \\
\hline
\end{tabular}

Sumber: Data diolah (2020)

Dalam pengujian validitas diketahui bahwa masing-masing Item memiliki nilai Loading Factor di atas 0,8 sehingga dapat dikatakan instrumen memiliki validitas yang cukup tinggi sedangkan reliabilitas berdasarkan nilai Cronbach's alpha juga di atas 0,8 sehingga instrumen dapat dikatakan reliabel (Hair et al., 2009).

Pengujian Hipotesis ditunjukkan pada Tabel 4.

Variabel CrM memiliki pengaruh terhadap Brand image karena nilai signifikansi di bawah 0,05 selain itu ditinjau dari nilai estimasi sebesar 0,837 menunjukkan bahwa terdapat pengaruh positif $\mathrm{CrM}$ terhadap Brand image yang berarti peningkatan $\mathrm{CrM}$ sebesar 1 akan menghasilkan peningkatan Brand image sebesar 0,837. Dengan demikian dapat dikatakan $\mathrm{H} 1$ diterima.

Variabel CrM memiliki pengaruh terhadap Sikap karena nilai signifikansi di bawah 0,05 selain itu ditinjau dari nilai estimasi sebesar 0,427 menunjukkan bahwa terdapat pengaruh positif CrM terhadap Sikap yang berarti peningkatan CrM sebesar 1 akan menghasilkan peningkatan Sikap sebesar 0,427 . Dengan demikian dapat dikatakan $\mathrm{H} 2$ diterima.

Tabel 4. Hasil Uji Hipotesis

\begin{tabular}{cclcc}
\hline No & Hipotesis & \multicolumn{1}{c}{ Pengaruh Variabel } & Estimate & CR \\
\hline 1 & H1 & CrM $\rightarrow$ Brand image & 0.837 & $14.01^{*}$ \\
\hline 2 & H2 & CrM $\rightarrow$ Sikap & 0.427 & $2.12^{*}$ \\
\hline 3 & H3 & CrM $\rightarrow$ Minat Beli & 0.023 & 0.08 \\
\hline 4 & H4 & Brand image $\rightarrow$ Sikap & 0.517 & $2.81^{*}$ \\
\hline 5 & H5 & Brand image $\rightarrow$ Minat Beli & 0.212 & 0.93 \\
\hline 6 & H6 & Sikap $\rightarrow$ Minat Beli & 0.597 & $2.07^{*}$ \\
\hline
\end{tabular}

Keterangan: *Signifikansi di bawah 0,05

Sumber: Data diolah (2020) 
Variabel CrM tidak memiliki pengaruh terhadap Minat Beli karena nilai signifikansi di atas 0,05 Dengan demikian dapat dikatakan H3 ditolak.

Variabel Brand image memiliki pengaruh terhadap Sikap karena nilai signifikansi di bawah 0,05 selain itu ditinjau dari nilai estimasi sebesar 0,517 menunjukkan bahwa terdapat pengaruh positif Brand image terhadap Sikap yang berarti peningkatan Brand image sebesar 1 akan menghasilkan peningkatan Sikap sebesar 0,517. Dengan demikian dapat dikatakan $\mathrm{H} 4$ diterima.

Variabel Brand image tidak memiliki pengaruh terhadap Minat Beli karena nilai signifikansi di atas 0,05 Dengan demikian dapat dikatakan H5 ditolak.

Variabel Sikap memiliki pengaruh terhadap Minat Beli karena nilai signifikansi di bawah 0,05 selain itu ditinjau dari nilai estimasi sebesar 0,597 menunjukkan bahwa terdapat pengaruh positif Sikap terhadap Minat Beli yang berarti peningkatan Sikap sebesar 1 akan menghasilkan peningkatan Minat beli sebesar 0,597. Dengan demikian dapat dikatakan $\mathrm{H} 6$ diterima.

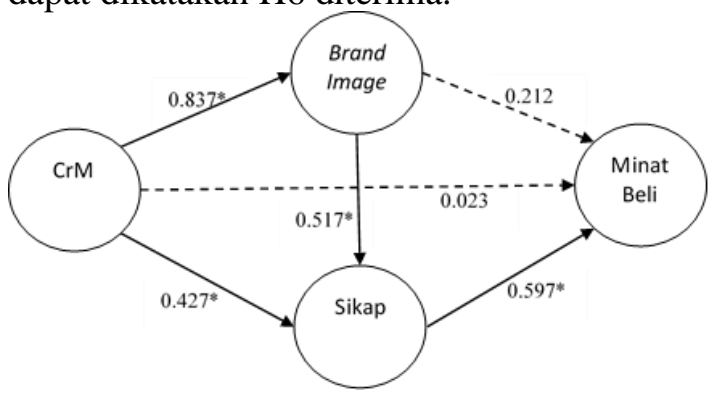

Gambar 2. Hasil Uji Hipotesis

Keterangan:

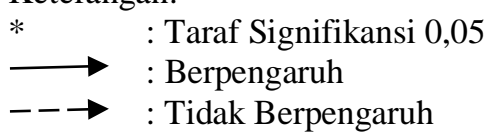

\section{Pembahasan}

Penelitian ini bertujuan untuk mengkaji pengaruh CrM terhadap Brand image, Sikap dan Minat pembelian restoran cepat saji Burger King. Berdasarkan hasil analisis dijelaskan bahwa CrM memiliki dampak pada peningkatan Brand image yang menunjukkan bahwa sebuah kampanye solidaritas ternyata mampu meningkatkan persepsi konsumen tentang pandangan terhadap sebuah merek. Hasil penelitian tersebut senada dengan Lin \& Lin (2019) yang mengungkapkan bahwa kegiatan CrM dalam bentuk penggalangan dana mampu memberikan pandangan positif akan kepedulian sosial perusahaan terhadap lingkungan sekitar sehingga mampu membangun citra yang positif perusahaan dari sudut pandang konsumen.

Hasil penelitian menunjukkan bahwa CrM memiliki pengaruh terhadap Sikap sehingga dapat dikatakan bahwa tanggapan positif Burger King sebagai sebuah restoran cepat saji yang bagus dan menarik dapat ditunjang dengan adanya kegiatan CrM Burger King. Penelitian ini didukung oleh pendapat Pandey et al. (2020) menjelaskan bahwa CrM menjadi sebuah alat pemasaran yang efektif dalam menghasilkan sikap positif terhadap sebuah produk ditinjau dari segi lamanya kampanye serta jenis perusahaan yang melaksanakan kegiatan CrM tersebut.

Brand image berpengaruh terhadap sikap sehingga dapat dikatakan semakin tinggi image sebuah merek dalam benak konsumen akan mendukung peningkatan terhadap sikap secara positif. Duarte \& Silva (2018) menambahkan bahwa cara yang paling tepat dalam membangun sikap positif konsumen adalah dengan melakukan kegiatan periklanan yang mampu menunjang citra sebuah merek sehingga mampu meningkatkan pandangan emosional yang positif dalam membangun hubungan terhadap konsumen dan merek.

CrM dan Brand image tidak memberikan dampak terhadap peningkatan minat pembelian yang berarti kegiatan CrM dan Brand image Burger King tidak mampu memberikan dampak yang bermaknda dalam mendorong minat beli konsumen. Chaabouni et al. (2020) menjelaskan bahwa kegiatan kampanye memiliki efektivitas apabila semakin konsumen tidak meragukan tujuan baik dari kampanye tersebut, jika konsumen merasa ragu atau semakin tinggi skeptisisme terhadap kampanye maka akan memberikan dampak yang negatif terhadap minat pembelian konsumen. Dengan demikian perlu dikaji lebih mendalam lagi bagaimana efektivitas CrM dan Brand image dari segi skeptisisme dan dampaknya pada minat pembelian.

\section{Kesimpulan}

Hasil temuan menunjukkan bahwa: (1) CrM memberikan pengaruh terhadap Brand 
image; (2) CrM memberikan pengaruh terhadap Sikap; (3) Brand image memberikan pengaruh terhadap Sikap; dan (4) Sikap memberikan pengaruh terhadap Minat Beli. Namun CrM dan Brand image tidak memberikan pengaruh yang bermakna terhadap Minat Pembelian produk Burger King. Dengan demikian dapat dikatakan bahwa CrM dan Brand image mampu memunculkan sikap positif namun tidak mampu menghasilkan minat pembelian konsumen.

Penelitian memiliki keterbatasan khususnya dalam jumlah sampel yang relatif sedikit karena tidak berjalan efektif dalam masa pandemi Covid 19 sehingga penelitian kedepannya perlu mengkaji dengan sampel yang lebih representatif dengan jumlah populasi. Penelitian juga hanya terbatas pada kajian bagaimana dampak positif dari kampanye namun tidak mengkaji bagaimana keraguan konsumen terhadap kampanye CrM sehingga perlu menjadi kajian lebih lanjut bagaimana keraguan konsumen terhadap kampanye CrM. Perlu kajian lebih mendalam tentang bagaimana efektivitas CrM ditinjau dari segi skeptisisme atau keraguan konsumen terhadap kegiatan CrM tersebut sehingga bagaimana dampaknya pada Brand image, Sikap dan Minat pembelian. Bagi para pelaku usaha bidang makanan cepat saji dengan merek yang sudah terkenal hendaknya memanfaatkan strategi $\mathrm{CrM}$ yang serupa dengan Burger King guna mendorong peningkatan citra merek atau brand image dan sikap konsumen dalam melakukan pembelian produk dan layanan yang ditawarkan.

\section{Daftar Referensi}

Badan Pusat Statistik. (2020). Laporan Bulanan Data Sosial Ekonomi. In Katalog BPS (Vol. 40, Issue September, pp. 1-116).

Baek, W. Y., Byon, K. K., Choi, Y. H., \& Park, C. W. (2017). Millennial consumers' perception of sportswear brand globalness impacts purchase intention in cause-related product marketing. Social Behavior and Personality, 45(8), 1319-1336. https://doi.org/10.2224/sbp.6225

Chaabouni, A., Jridi, K., \& Bakini, F. (2020).
Cause-related marketing: scepticism and warm glow as impacts of donation size on purchase intention. International Review on Public and Nonprofit Marketing, 129-150. https://doi.org/10.1007/s12208-02000262-3

Charton-Vachet, F., Lombart, C., \& Louis, D. (2020). Impact of attitude towards a region on purchase intention of regional products: the mediating effects of perceived value and preference. International Journal of Retail and Distribution Management, 48(7), 707725. https://doi.org/10.1108/IJRDM-092019-0315

Cho, E., Lee, J., \& Lee, Y. (2017). Corporate philanthropy affecting consumer patronage behavior: The effect of reciprocity and the moderating roles of vicarious licensing and strategic fit. Sustainability (Switzerland), 9(7), 1-15. https://doi.org/10.3390/su9071094

Diehl, S., Terlutter, R., \& Mueller, B. (2016). Doing good matters to consumers: The effectiveness of humaneoriented CSR appeals in cross-cultural standardized advertising campaigns. International Journal of Advertising, 35(4), 730-757. https://doi.org/10.1080/02650487.2015. 1077606

Duarte, P. A. de O., \& Silva, S. C. e. (2018). The role of consumer-cause identification and attitude in the intention to purchase cause-related products. International Marketing Review, 37(4), 603-620. https://doi.org/10.1108/IMR04-2018-0159

Eastman, J. K., Smalley, K. B., \& Warren, J. C. (2019). The Impact of Cause-Related Marketing on Millennials' Product Attitudes and Purchase Intentions. Journal of Promotion Management, 25(6), 799-826. https://doi.org/10.1080/10496491.2018. 1536625

Ferraris, A., Giudice, M. Del, Grandhi, B., \& Cillo, V. (2019). Refining the relation between cause-related marketing and consumers purchase intentions: A crosscountry analysis. International 
Marketing Review, 37(4), 651-669. https://doi.org/10.1108/IMR-11-20180322

Hair, J., Anderson, R., Black, B., \& Babin, B. (2009). Multivariate Data Analysis. Pearson Education.

Hashem, T. (2020). Can Cause-Related Marketing (CRM) 'Light' up the Brand image? An Insight into the Perceptions of Jordanian Consumers. European Journal of Business and Management, January. https://doi.org/10.7176/ejbm/12-36-02

Kasilingam, D. L. (2020). Understanding the attitude and intention to use smartphone chatbots for shopping. Technology in Society, 62(February), 101280. https://doi.org/10.1016/j.techsoc.2020.1 01280

Kotler, P., \& Keller, K. L. (2015). Marketing Management, Global Edition. Pearson Education Limited.

Lerro, M., Raimondo, M., Stanco, M., Nazzaro, C., \& Marotta, G. (2019). Cause related marketing among Millennial consumers: The role of trust and loyalty in the food industry. Sustainability (Switzerland), $11(2)$. https://doi.org/10.3390/su11020535

Lin, S. C., \& Lin, M. T. Y. (2019). A study of the effects of cause-related marketing on brand image and purchase intention in ecotourism. Ekoloji, 28(107), 28872892.

Maharani Feminingtyas, A., \& Mayangsari, L. (2020). The Influence of Cause Related Marketing Towards Purchase Intention in Local Fashion Brands Indonesia. $K n E$ Social Sciences, 2020, 1106-1119. https://doi.org/10.18502/kss.v4i6.6665

Pandey, S., Chawla, D., Jeong, L. S., Bautista, R., \& Santos, J. E. (2020). An Experimental Approach to Examine the Antecedents of Attitude, Intention, and Loyalty Towards Cause-related Marketing: The Case of India and the Philippines. Global Business Review. https://doi.org/10.1177/0972150919901 186

Park, J. Y., \& Sihombing, S. O. (2020).
Effects of Sponsor-Event Congruence on Brand image, Attitude Toward the Brand, and Purchase Intention: an Empirical Analysis in the Context of Sport Sponsorship. Jurnal Aplikasi Manajemen, 18(1), 14-27. https://doi.org/10.21776/ub.jam.2020.01 8.01.02

Partouche, J., Vessal, S., Khelladi, I., Castellano, S., \& Sakka, G. (2020). Effects of cause-related marketing campaigns on consumer purchase behavior among French millennials: A regulatory focus approach. International Marketing Review, 37(5), 923-943. https://doi.org/10.1108/IMR-12-20180348

Patel, J. D., Gadhavi, D. D., \& Shukla, Y. S. (2017). Consumers' responses to cause related marketing: moderating influence of cause involvement and skepticism on attitude and purchase intention. International Review on Public and Nonprofit Marketing, 14(1). https://doi.org/10.1007/s12208-0160151-1

Ramesh, K., Saha, R., Goswami, S., Sekar, \& Dahiya, R. (2019). Consumer's response to CSR activities: Mediating role of brand image and brand attitude. Corporate Social Responsibility and Environmental Management, 26(2), 377387. https://doi.org/10.1002/csr.1689

Surianto, M. A., Setiawan, M., Sumiati, \& Sudjatno. (2020). Cause-related marketing campaigns and repurchase intentions: The mediating role of brand awareness, consumer attitude and corporate image. Management Science Letters, $\quad$ 10(14), 3235-3242. https://doi.org/10.5267/j.msl.2020.6.015

Wiguno, D., Yunikawati Wibowo, D., Aprilia, A., \& Andreani, F. (2014). Segmentasi Konsumen Makanan Cepat Saji Online Di Surabaya Secara Demografis Dan Psikografis. Universitas Kristen Petra, 292-307.

https://media.neliti.com/media/publicati ons/84899-ID-segmentasi-konsumenmakanan-cepat-saji-o.pdf

Wijayayanto, S. (2018). Pengaruh Brand 
image, Attitude, Dan Service Quality Terhadap Keputusan Beli Konsumen. Jurnal Manajemen Dewantara, 2(2), 95104.

Wulandari, A., \& Riptiono, S. (2020). Pengaruh Celebrity Image Congruence dan Brand Experience Terhadap
Purchase Intention Melalui Brand Attitude Sebagai Variabel Intervening. Jurnal Ilmiah Mahasiswa Manajemen, Bisnis Dan Akuntansi (JIMMBA), 2(5), 778-787.

https://doi.org/10.32639/jimmba.v2i5.61 1 